\title{
PEMANFAATAN UJI KOMPETENSI DENGAN GOOGLE FORM PADA PEMBELAJARAN PELATIHAN KEMANDIRIAN LEMBAGA PEMASYARAKATAN (LAPAS) JAKARTA
}

\author{
Dewi Rahmawaty ${ }^{1}$ \\ ${ }^{1}$ Desain Busana, Desain Produk, Sekolah Tinggi Desain Interstudi, Jakarta \\ email: dewi.stdi@interstudi.edu
}

\begin{abstract}
Abstrak
Pengabdian masyarakat ini bertujuan untuk mengetahui pemanfaatan google form saat ujian pada saat pelaksanaan Pelatihan Kemandirian di Lembaga Pemasyarakatan Jakarta Tahun 2021. Pelatihan kemandirian merupakan suatu pelayanan bagi warga binaan berupa pelatihan kemandirian di bidang manufaktur seperti kegiatan kecakapan hidup pengelasan, perbaikan ac, pembuatan kandang burung, dan lain lain bidang jasa seperti barber shop, digital printing, sablon dan lain lain. Bidang agrobisnis seperti budidaya tanaman dan budidaya ikan, ayam, dan lain lain, dan terakhir bidang boga mulai dari masakan nusantara, internasional, kue basah dan kue kering serta minuman kekinian dan jamu aserta barista. Setelah warga binaan mendapatkan materi pelatihan akan diakhiri dengan ujian, dan pelatihan kemandirian menggunakan layanan google form sebagai alat untuk mengambil nilai, selain hemat waktu, tenaga, juga dalam apliaksi google form bisa langsung di skoring, sehingga dapat dilihat statistik nilai dari jenis pelatihan bidang yang mendapatkan skor dari masing masing warga binaan sebagai peserta. Pada pelatihan kemandirian ini bidang tata boga yang mendapatkan nilai tertinggi sampai 100 dari 1 warga binaan dan nilai yang sering muncul di skor 80, sedangkan bidang dengan tingkat skoring terendah dari bidang lain yaitu pengelasan dengan skor tertinggi 75 dan skor terendah 40. Bidang lainnya seperti sablon dan pembuatan hand saniziter berada dengan nilai yang sering muncul atau modus 85 .
\end{abstract}

Kata kunci: Lapas, Google form, Partsipatoris, Warga Binaan

\begin{abstract}
This community service aims to determine the use of google form during exams during the implementation of the Independence Training at the Jakarta Penitentiary in 2021. Self-reliance training is a service for assisted residents in the form of self-reliance training in manufacturing such as welding life skills, air conditioning repair, making bird cages, and others in the field of services such as barber shops, digital printing, screen printing and others. The agribusiness sector, such as plant cultivation and fish, chicken, and others, and finally the culinary sector, ranging from domestic, international, pastries and pastries as well as contemporary drinks and jamu as well as baristas. After the assisted residents get the training material, it will end with an exam, and self-reliance training using the google form service as a tool to take scores, in addition to saving time, energy, also in the google form application can be scored directly, so that the statistical value of the type of field training can be seen. get a score from each of the assisted residents as a participant. In this self-reliance training, the culinary sector received the highest score of up to 100 from 1 assisted citizen and the score that often appeared was 80, while the field with the lowest scoring level from other fields was welding with the highest score of 75 and the lowest score of 40 . Other fields such as screen printing and the manufacture of hand sanitizers with a value that often appears or mode 85 .
\end{abstract}

Keywords: Prison, Google form, Participatory, Assisted Citizens

\section{PENDAHULUAN}

Pandemi Covid 19 yang telah ada sejak Maret 2020 membuat banyak perubahan dalam pembelajaran baik tingkat pendidikan dasar, menengah sampai perguruan tinggi sampai Pendidikan Non Formal. Strategi serta metode pembelajaran digunakan untuk mendapatkan kecocokan dalam pembelajaran. Pendidikan Non Formal adalah suatu jenjang pendidikan di bidang non formal/luar sekolah yang lebih banyak persentase jam praktek daripada teori sehingga ketepatan pemilihan 
strategi pembelajaran desain menjadi kunci utama dalam meningkatkan minat mahasiswa dalam keberlangsungan kegiatan belajar mengajar.

Para Warga Binaan mendapatkan pelatihan kemandirian sebagai bekal mereka kelak saat bebas, pilihan pelatihan kemandirian disesuaikan dengan kebutuhan jaman berdasarkan revolusi industry 4.0 dan society 5.0. Pelatihan kemandirian yang ada diantaranya bidang manufaktur, boga, jasa dan agrobisnis. Pilihan bidang disesuaikan dengan minat dan bakat para warga binaan agar menjadi penyemangat saat mereka menjalankan pelatihan kemandiriannya. Pelatihan Kemandirian tidak hanya mengajarkan hardskill namun juga softskill, hard skill mengasah kemampuan mereka secara kognitif dari tidak tahu menjadi tahu serta psikomotor dari kekakuan menggerakan alat alat praktek menjadi terbiasa menggunakan alat praktek.

Pembelajaran dilakukan mulai dari pengenalan alat bahan, sejarah konsep dan pemahaman suatu topik, dilanjutkan praktek mengerjakan suatu produk, warga binaan mengikuti semua tahapan. Proses berikutnya adalah persiapa ujian, ujian dilaksanakan dengan memanfaatkan google form sebagai media penialaian. Hal ini dapat mengurangi limbah kertas dan juga memudahkan penskoring yang lebih cepat.

\section{METODE}

Metode yang digunakan dalam penulisan ini adalah partisipatoris, yaitu keterlibatan warga binaan dalam proses Pengabdian Masyarakat. Metode partisipatif yaitu mendorong keikutsertaan setiap individu didalam suatu proses kelompok tanpa memandang usia, jenis kelamin, kelas sosial dan latar belakang pendidikan yang tumbuh dari rasa kesadaran dan tanggung jawabnya. Metode partisipasi merupakan salah satu jenis penelitian kualitatif yang lebih melihat fenomena secara lebih luas dan mendalam sesuai dengan apa yang terjadi dan berkembang pada situasi sosial yang diteliti. Dalam penelitian kualitatif, penentuan fokus lebih didasarkan pada tingkat kebaruan informasi yang akan diperoleh dari situasi sosial (lapangan). Lebih lanjut, Sugiono menjelaskan kebaruan informasi yang akan diperoleh dari situasi sosial, tetapi juga ada keinginan untuk menghasilkan hipotesis atau ilmu baru dari situasi sosial yang diteliti. Fokus yang sebenarnya dalam penelitian kualitatif diperoleh setelah peneliti melakukan grand observation dan grand question atau yang disebut penjelejahan umum.

Secara metodologis, bentuk bentuk pasrtisipasi dalam melakukan observasi meliputi (suginono, 2009) (1) Partisipasi aktif (passife participation: means the research is present at the scene of action but does not interact or participate). Jadi dalam hal ini peneliti datang di tempat kegiatan orang yang diamati, tetapi tidak terlibat dalam kegiatan tersebutt (2) Partisipasi moderat (moderat partisipasion): means hat the researcher main tains a balance between being insider and being outsider. Dalam observasi ini terdapat keseimbangan antara peneliti menjadi orang dalam dengan orang luar. Peneliti dalam mengumpulkan data harus ikut observasi partisipatif dalam beberapa kegiatan, tetapi tidak semua nya (3) Partisipasi aktif (Active Pasrtisipation) : means that the researcher generally dose what others in he setting do (4) Partisipasi Lengkap (complete Partisipatipan) : means the researcher is a natural participant. This is the highes level of involvement. Peneliti sudah terlibat sepenuhnya terhadap apa yang dilakukan sumber data. Jadi suasana nya sudah natural, penelit yang tertinggu terhafap aktivitas kehidupan yang diteliti.

Selama proses kegiatan belajar mengajar dalam pelatihan kemandirian berlangsung dimulai dengan pembukaan. Pengenalan alat dan bahan sesuai bidang pelatihan kemandirian, lalu dilakukan brain storming untuk caracther building serta pengenalan usaha dan prospek dari bidang pelatihan yang akan di geluti. Di hari berikutnya yaitu praktek pembelajaran dilakukan secera klasikal, dengan pembagian kelompok, dan diakhir dengan ujian online.

Dalam observasi partisipatif ini, peneliti terlibat dengan kegiatan warga binaan dalam kegiatanya selama mengikuti pelatihan kemandirian. Susan Sainback (1988) menyatakan, In participant observation, the researcher in their what people do, listen to what they say, and participates inther activities". Dalam metode ini, selama pelatihan kemandirian berlangsung, warga binaan pu terlibat secara langsung didalamnya. 


\section{HASIL DAN PEMBAHASAN}

Penggunaan google form selain untuk survey dan sejenisnya juga dapat dimanfaatkan sebagai sarana untuk ujian online. Seperti yang selama ini banyak digunakan oleh para guru baik di tingkat sekolah dasar, menengah, dan tinggi. Para guru memanfaatkan layanan google form selama pembelajaran jarak jauh karena pandemic covid. Pada google form bisa dibuat berbagai model soal sesuai kebutuhan dari guru dan kedalam materi yang akan ditanyakan oleh guru. Bentuk soal mulai dari pilihan ganda, dengan beberapa pilihan jawaban, bentuk soal essay yang memerlukan jawaban singkat, maupun dengan penjelasan. Untuk membuat google form pastinya harus memiliki akun google. Disini pihak penyelanggara dari pelatihan kemandirian menyiapkan perangkat smart phone yang sudah di setel link soal untuk bisa di jawab oleh warga binaan. Soal sudah diberi bobot point dan dilengkapi dengan skor di akhir pengerjaan soal.

Tabel 1. Hasil Skoring nilai Ujian Pelatihan Kemandirian Tata Boga

\begin{tabular}{|l|c|}
\hline \multicolumn{1}{|c|}{ Nama Warga Binaan } & Nilai \\
\hline Muh. Arief Ghazali & 75 \\
\hline Rudi Iskandar & 90 \\
\hline Septian Eka Putra Irawan & 80 \\
\hline Khairul Fannan & 90 \\
\hline Susanto & 80 \\
\hline Endro Joso Susanto & 85 \\
\hline Herman & 75 \\
\hline Juhairi Bachtiar bin Salmen & 85 \\
\hline Wahyu Yani A & 80 \\
\hline Rodi Hartono & 85 \\
\hline Januar Anggara & 85 \\
\hline Endang Soeryana & 70 \\
\hline Firman Okta Surya & 75 \\
\hline Ridwan Virgo Rizal & 95 \\
\hline M.Latif Nursaeha & 95 \\
\hline Juanda & 100 \\
\hline Beni Supriatin & 40 \\
\hline Adam Kusmayadi & 80 \\
\hline Sanuri Saputra & 70 \\
\hline
\end{tabular}

$\begin{array}{ccc}\text { Rata-rata } & \text { Median } & \text { Rentang } \\ 80,79 / 100 \text { poin } & 80 / 100 \text { poin } & 40-100 \text { poin }\end{array}$

Distribusi poin total

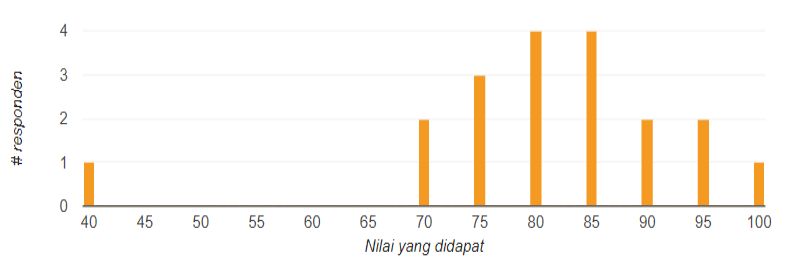

Diagram 1. Hasil Skoring Pelatihan Kemandirian Bidang Boga

Pelatihan Kemandirian Bidang Boga ditunjukan pada tabel skor yang didapat warga binaan dengan nilai tertinggi 100 dan terendah 40, sedangkan rerata nya ada di nilai 80. Peserta pelatihan kemandirian bidang dalam menerima materi dibuat ke dalam kelompok kecil, saat materi teori serta praktek. Bobot penyajian materi menggunakan 30 persen teori dan 70 persen praktek. 


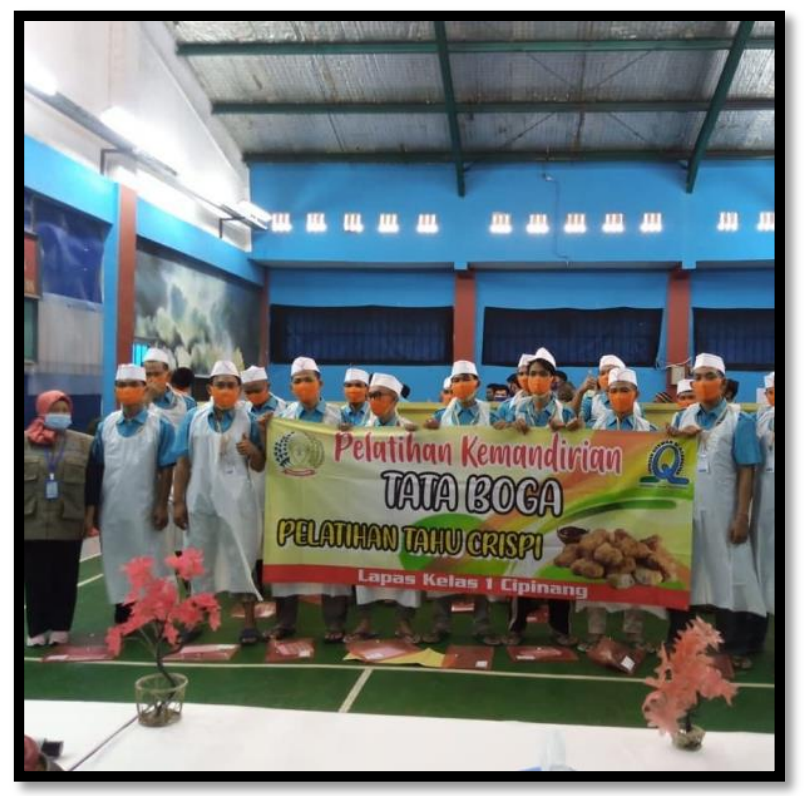

Tabel 2. Hasil Skoring Nilai Ujian Pelatihan Kemandirian Bidang Pengelasan

\begin{tabular}{|l|c|}
\hline \multicolumn{1}{|c|}{ Nama WB } & Nilai \\
\hline Tarsidi & 80 \\
\hline Wahyu Wijaya & 55 \\
\hline Ahmad Indrawan M & 55 \\
\hline Ichwan Nul Hakim & 75 \\
\hline David Susanto & 60 \\
\hline Regi Ardiansyah & 60 \\
\hline Samsul & 45 \\
\hline David Daud & 85 \\
\hline Nur Wahid & 75 \\
\hline Ferdy Hikmawan & 80 \\
\hline Sinyo Moniaga & 65 \\
\hline Azizon & 55 \\
\hline Sukamto & 85 \\
\hline Onang & 45 \\
\hline Moch Topan & 65 \\
\hline Andi Cakra & 65 \\
\hline Joy Farhan & 70 \\
\hline Andy Bechand & 60 \\
\hline Mario & 45 \\
\hline
\end{tabular}




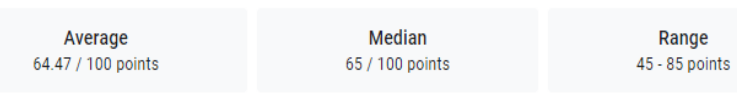

Total points distribution

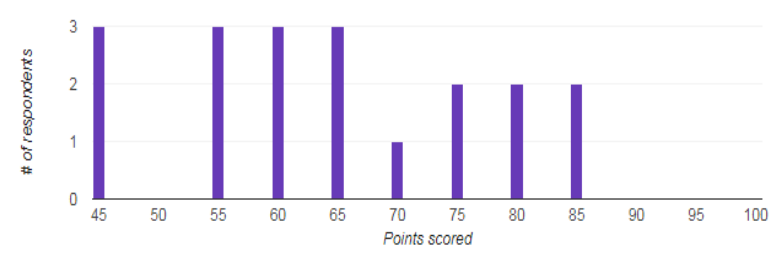

Diagram 2. Hasil Skoring Pelatihan Kemandirian Bidang Pengelasan
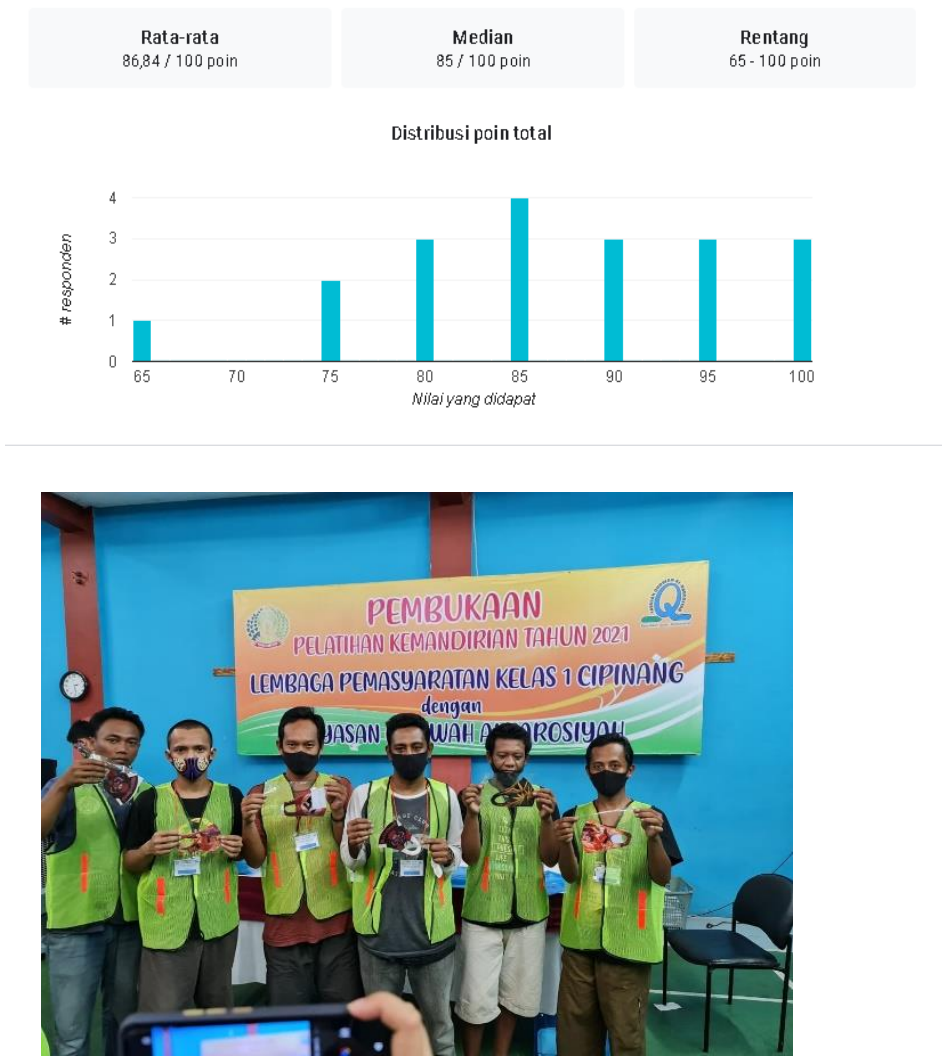

Pelatihan Kemandirian Bidang Manufaktur pengelasan ditunjukan pada tabel skor 2 yang didapat warga binaan dengan nilai tertinggi 85 dan terendah 45. Peserta pelatihan kemandirian bidang manufaktur pengelasan umumnya masih sedikit kesulitan memahami istilah istilah yang ada dalam ujian di perangkat google form, walau saat kegiatan belajar mengajar instruktur sudah membuat glosairium. Materi dikemas sedemikian rupa dengan bobot penyajian materi menggunakan 20 persen teori dan 70 persen praktek. Presentasi teori yang hanya 20 persen yang menyebabkan warga binaan tidak cakap menjawab soal yang ada di dalam google form. 
Tabel 3. Hasil skoring Pelatihan Kemandirian Bidang Jasa Sablon Masker

\begin{tabular}{|l|c|}
\hline \multicolumn{1}{|c|}{ Nama WB } & Nilai \\
\hline Cipta Budi Siahaan & 85 \\
\hline Lilik Ardianto & 75 \\
\hline Wahyu De Santo & 100 \\
\hline Donny Achmad & 95 \\
\hline Clinton Willyam & 85 \\
\hline Ara supratmara & 90 \\
\hline Muhamat Robby & 90 \\
\hline Ade Bastian & 80 \\
\hline Kiki Hijriah & 90 \\
\hline Rangga Suryanto & 100 \\
\hline Abdul Ajis & 95 \\
\hline Toni & 100 \\
\hline Robby Wijaya & 65 \\
\hline Suwandi & 80 \\
\hline Intan Setia & 75 \\
\hline Adhy Kusmaryadi Nugraha & 85 \\
\hline Rio Rusmanto & 85 \\
\hline
\end{tabular}

Diagram 3. Hasil Skoring Pelatihan Kemandirian Bidang Jasa Sablon Masker

Pelatihan Kemandirian Bidang jasa sablon masker ditunjukan pada tabel skor 2 yang didapat warga binaan dengan nilai tertinggi 100 dan terendah 75. Peserta pelatihan kemandirian bidang jasa sablon masker sudah memiliki pemahaman yang baik dalam teori, terbukti dengan baikya sebaran nilai yang ada di statistik nilai. Paparan soal perangkat google form yang mudah dipahami menjadi faktor penentu mereka dalam menjawab soal soal yang ada.

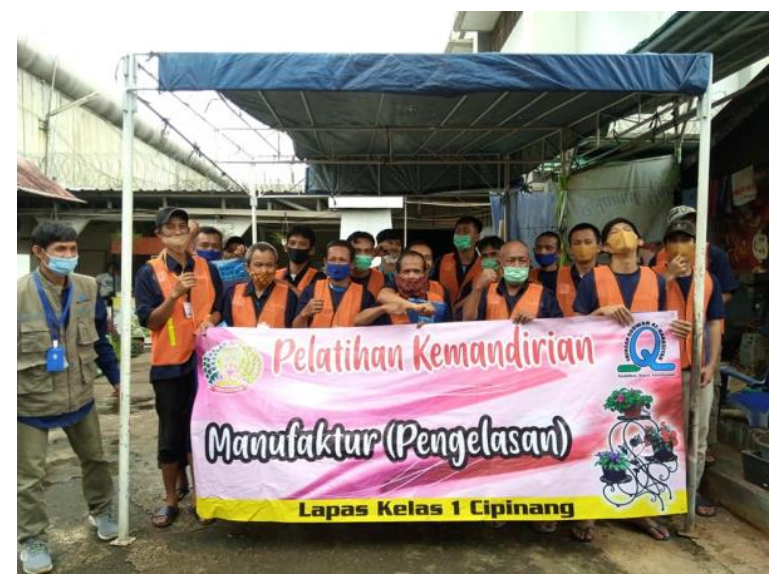


Tabel 4. Hasil Skoring Nilai Ujian Pelatihan Kemandirian Pembuatan Hand Sanitizer

\begin{tabular}{|l|c|}
\hline \multicolumn{1}{|c|}{ Nama WB } & Nilai \\
\hline Dede Heryan & 95 \\
\hline Hariyanto & 90 \\
\hline TB Muksin & 95 \\
\hline Rehan & 70 \\
\hline M Yusuf & 80 \\
\hline Iksan Saripudin & 80 \\
\hline Rizal Pramadi & 75 \\
\hline Mus Septian & 85 \\
\hline Hanafi & 75 \\
\hline Moh Taryono & 80 \\
\hline Budi Wahyono & 80 \\
\hline Moh Dika & 75 \\
\hline Taufik Budiman & 85 \\
\hline Muhamad Sanusi & 70 \\
\hline Resti & 100 \\
\hline
\end{tabular}

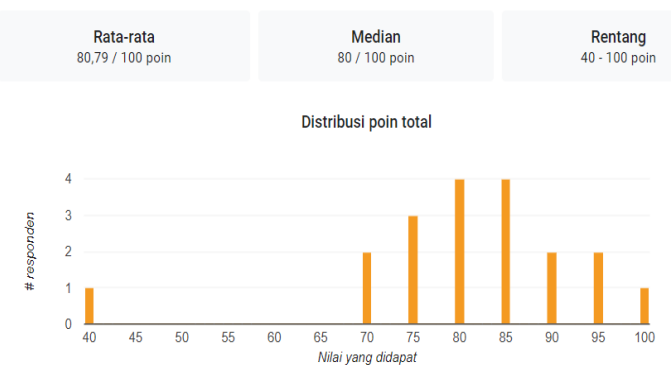

\section{Diagram 4. Hasil Skoring Pelatihan Kemandirian Pembuatan Hand Sanitizer}

Skor atau nilai pada tabel Pelatihan Kemandirian pembuatan hand sanitizer, menunjukan sebaran nilai tertinggi di 100 dan nilai terendah pada skor 75. Pada kegiatan belajar mengajar materi pembuatan sablon masker, instruktur memberi persentasi teori sebesar 30persen dan praktek 70 persen. Pelatihan kemandirian yang diikuti oleh 80 warga binaan yang terdiri dari 20 orang mengikuti pelatihan kemandirian bidang boga, 20 warga binaan bidang manufaktur, 20 warga binaan bidang jasa sablon masker, dan 20 warga binaan bidang hand sanitizer.

\section{SIMPULAN}

Kegiatan belajar mengajar pada pelatihan kemandirian Warga binaan di Lembaga Pemasyarakatan selama 14 hari kerja, yang dilaksanakan dengan empat bidang yaitu bidang manufaktur, jasa, boga dan agrobisnis. Pelatihan kemandirian dilaksanakan pertama dengan pengenalan alat bahan, konsep dan teori, membrain storming bagaimana warga binaan menekuni bidang pelatihan ini ke depannya, hari berikutnya dilakukan dengan praktek dan teori teori pendukung, serta di hari terkahir yaitu dengan diadakan ujian. 
Selama masa pengambilan nilai, dilakukan dengan memanfaatkan google form sebaga media dalam pengambilan penilaian teori. Selain lebih praktis juga lebih cepat karena penilaian atau skor bisa langsung dilihat tdalam hitungan detik, selain itu juga mengurangi limbah kertas yang akan mengurangi limbah kertas.

Dari kegiatan pelatihan kemandirian yang dilakukan, bidang las adalah bidang dengan nilai yang cukup sulit di raih oleh warga binaan, nilai yang paling sering muncul atau modud di bidang ni hanya di skor 75, sedangkan nilai terkecil dengan skor 40. Sedangkan bidang dengan nilai skor terbaik yaitu bidang boga, banyak yang mendapat nilai bagus bahkan skor sempurna didapat oleh warga binaan darai bidang boga. Untuk bidang lainnya memiliki kesamaan skor yaitu di nilai atau skor yang paling sering muncul di angka 80 . Yaitu bidang hand sanitizer dan sablon masker.

Antusiasme warga binaan dalam penggunaan ujian kompetensi dengan google form menjadi suatu pengalaman baru mereka, karena selama ini mereka belum pernah merasakan ujian dengan menggunakan google form. Saran untuk penulis lanjutan adalah bagaimana mengukur butir soal dengan tingkat sukar dan dengan tingkat sedang bahkan rendah yang akan mempengaruhi nilai atau skor warga binaan.

\section{Daftar Pustaka}

Anggraini, L, 2007, Sistem Ujian Online dan Penilaian Siswa Berbasis Web pada SMA PGRI 109 Tangerang : Skripsi, Fakultas Teknik, Universitas Mercu Buana, Tangerang.

Arikuntp, Suharsimi (2013), Prosedur Penelitian : Suatu Pendekatan Praktik, Jakarta : Rineka Cipta

Belawati T (2020) Pembelajara Online. Tangeranf Selatan : Universotas Terbuka

Bilfaqih Y \& Qomarudin NM (2015) Esensi Pengembangan Pembelajaran Daring. Edisi 1 Cet 1 Yogyakarta : Deepublish

Anwar Yesmil, Kriminologi, Refika Aditama, Bandung, 2013

Cahyadi A (2019) Pengembangan Media dan Sumber Belajar : Teori dan Prosedur. Serang : Penerbit Laksita Indonesia

Direktur Pendidikan dan Pembelajaran (2014). Pedoman Penjaminan Mutu Penyelenggaraan Pembelajaran Daring Indonesia Terbuka dan Terpadu. Jakarta : idrektur Pembelajaran dan Kemahasiswaan

Direktorat Pembelajaran (2019). PAndua Prose Pembelajaran Daring SPADA 2019. Jakarta :

Kementrian Riset

Fathurohman M (2013). Model Pembelajarab Invatif Alternatif Desain Pembelajaran yang menyenangkan. ED I. Jogyakarta : Ar-RUZZ Media

Muljono Wahyu, Pengantar Teori Krimimologi, Pustaka Yustia, Yogyakarta, 2012

Sugiyono (2018). Metode PEnelitian Kualitatif. Bandung : Alfabeta, CV 